\title{
圧着エ法によるフリップチップの接続マージン評価
}

\author{
廣畑 賢治*, 川村 法靖**, 向井 稔 ${ }^{* *}$, 川上 崇 ${ }^{* *}$, 瀬川 雅雄 ${ }^{* *}$, 高橋 邦明**** \\ 于 強*****, 白鳥 正樹*****
}

\section{Evaluation for Flip-Chip Bonding Margin Using Anisotropic Conductive Paste}

Kenji HIROHATA ${ }^{*}$, Noriyasu KAWAMURA ${ }^{* *}$, Minoru MUKAI $^{* *}$, Takashi KAWAKAMI ${ }^{* *}$, Masao SEGAWA ${ }^{* * *}$, Kuniaki TAKAHASHI ${ }^{* * *}$, Qiang $\mathrm{YU}^{* * * * *}$ and Masaki SHIRATORI*****

\footnotetext{
*株式会社東芝研究開発センター機械・システムラボラトリー／横浜国立大学大学院工学研究科（†212-8582 神奈川県川崎市幸区小向東芝町1）

**株式会社東芝研究開発センター機械・システムラボラトリー（２12-8582 神奈川県川崎市幸区小向東芝町1）

***株式会社東芝生産技術センター生産技術企画部（テ235-0017 神奈川県横浜市磯子区新磯子町33）

****株式会社東芝デジタルメディアネットワーク社（テ198-8710 東京都青梅市末広町2-9）

$* * * * *$ 横浜国立大学工学部生産工学科（广240-8501 神奈川県横浜市保土ヶ谷区常盤台79-5）

* Research and Development Center, Toshiba Corporation/Department of Mechanical Engineering, Graduate School, Yokohama National University (1 Toshiba-cho, Komukai, Saiwai-ku, Kawasaki-shi, Kanagawa 212-8582)

**Research and Development Center, Toshiba Corporation (1 Toshiba-cho, Komukai, Saiwai-ku, Kawasaki-shi, Kanagawa 212-8582)

*** Manufacturing Engineering Center, Toshiba Corporation (33 Shin-Isogo-cho, Isogo-ku, Yokohama-shi, Kanagawa 235-0017)

$* * * *$ Degital Media Network Company, Toshiba Corporation (2-9 Suehiro-cho, Ome-shi, Tokyo 198-8710)

$* * * *$ Department of Mechanical Engineering, Yokohama National University (79-5 Tokiwadai, Hodogaya-ku, Yokohama 240-8501)
}

概要 接続用樹脂を用いた圧着工法によるフリップチップでは多くの場合, 製造プロセス後において, 金バンプ／゚ッド 界面に残留する圧縮荷重により電気的接続が保たれている。樹脂の選定やボンディング荷重（B'g荷重）の設定によっては, 高温吸湿試験において樹脂の膨潤により接続オープンが発生する場合がある。本報告では，接続用樹脂特性評価，フリップチ ップ試作品接続抵抗值のボンディング荷重依存性評価, 応力シミュレーションを組み合わせることにより, 接続マージンを定 量化する方法を提案した。さらに，応答曲面法を用いることにより，設計に内在するぼらつき要因が接続マージンに及ほす影 響を効率的に把握できることを示した。

\begin{abstract}
In the flip-chip packages using Anisotropic Conductive Paste, the load, which remain in the interface between $\mathrm{Cu}$ pad and $\mathrm{Au}$ bump after manufacturing process, keeps contact resistance stable. According to the resin properties or bonding(B'g) load, the contact resistance may be high and unstable in the reliability test such as high temperature and high humid tests. In this paper, in order to assess the bonding margin, the stress simulation through B'g process was carried out after the evaluation of resin properties. Then, the compressive load, which exists in the interface between $\mathrm{Au}$ bump and $\mathrm{Cu}$ pad, was generated. Using the results of stress simulation, the B'g margin was evaluated by comparing with the experimental results of the relationship between B'g load and contact resistance after B'g process. Furthermore, using response surface methodology, considerations have been given to reveal the effect of various scatters such as material characteristics and manufacturing on the B'g margin.
\end{abstract}

Key Words: Flip-Chip Interconnection, Anisotropic Conductive Paste, Stress Simulation, Response Surface Methodology, Statistical Analysis

\section{1.はじめに}

電子機器の軽薄短小化が加速し, 搭載部品に対する小型 化の要求が一段と高まっている。こうした背景のもと，高 密度実装が可能なフリップチップ接続技術の開発が活発に 行われている。圧着工法によるフリップチップでは, 多く の場合，接続用樹脂を介してチップのスタッドバンプと基 板電極を熱圧着し接続を行う ${ }^{1 \sim 9)}$ 。接続用樹脂としては, 異方性導電性フィルム $(\mathrm{ACF})$, 異方性導電ペースト $(\mathrm{ACP})$ ，導電粒子なしの樹脂ペースト/フィルム (NCP/NCF) などが用いられている。接続信頼性を確保
するのにバンプ周辺を樹脂で固着・封止する構造をとって いるため, 樹脂選定はフリップチップ実装の高信頼性化に とってきわめて重要である。樹脂選定やボンディング荷重 （B'g荷重）の設定によっては，高温・吸湿試験において樹 脂の膨潤により接続オープンや電気抵抗の上昇が発生する 場合がある。圧着工法によるフリップチップの場合, Fig. 1 に示すように，B'g荷重および樹脂の硬化収縮・応力緩 和・熱収縮により最終的な金バンプ／パッド界面圧縮荷重 つまり接続マージンが決まる。長期信頼性を確保するには, 樹脂特性やB'g荷重の影響度の明確化が重要課題になる。 本報告では, 応力シミュレーションを実施し, 試作品初期 


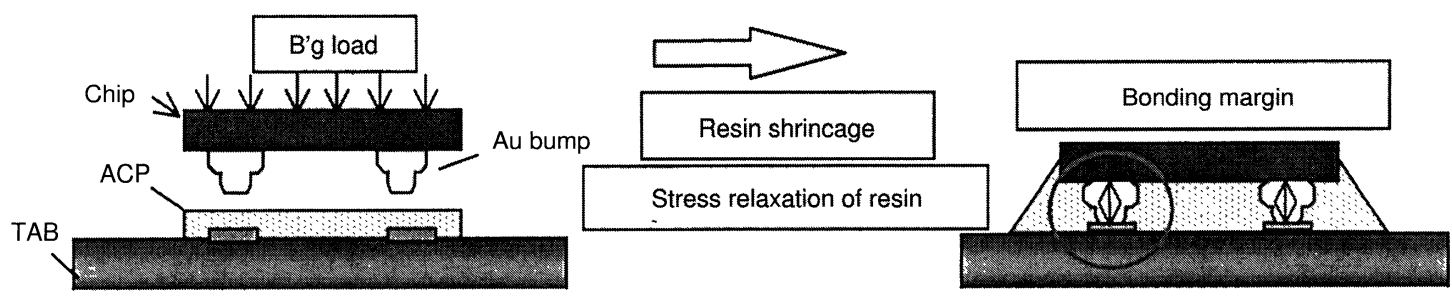

Fig.1 Bonding mechanism in flip-chip interconnection using ACP

接続抵抗值のB'g荷重依存性結果と照らし合わせ, バンプ 接合部の接続マージンを定量化した。さらに，応答曲面法 をべースとした統計的信頼性設計手法を適用することによ り，設計に内在するばらつきが接続マージンに及ぼす影響 を把握し，B'g荷重の設定や公差の設定を支援することを 試みた。

\section{2. 接続マージン解析 ${ }^{10)}$}

\section{1 対象}

Fig. 2 に示す小型画像センサーモジュール（試作品）: TOG(TAB on Glass) $)^{1}$ を対象に評価を実施した。この試作 品は, CMOSチップ, 光学ガラス拉よびTABテープによ り構成されている。接続用樹脂としては異方性導電ペース 卜（ACP）を用いている。製造プロセスをFig. 3 に示す。 まず, TABテープの裏面に接着郕を塗布し, 光学ガラス を接着する。 $\mathrm{TAB}$ テプの基材はポリイミドで，イメー ジエリアに相当する位置に開口部を設けてある。接着は紫 外線硬化型接着剈により行われる。この方法により, $10 \mu \mathrm{m}$ 以下の光学精度が容易に確保できる。次に, CMOS チップの $\mathrm{Al}$ 電極パッドにワイヤボンディング法などによ り，金バンプを形成する。TABテープの電極上には， $\mathrm{ACP}$ 塗布し，光学ガラス付きのTABテープに, CMOS チップをフリップチップ接続する。ここで，熱圧着により，

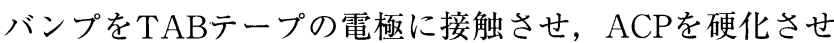
ることで，確実な接続特性と同時に封止構造も確保するこ とが可能となる。

\section{2 応カシミュレーションモデル}

Siチップと TABjよびガラス間の線膨張率差に起因す るバンプ部のせん断変形が顕著な場合は，バンプを 3 次元 でモデル化し，境界条件として，せん断変形を考慮する必 要があると考えられる。しかし本対象の場合，モジュール の全体応力解析を実施した結果，硬化温度から室温に降温 した際，金バンプ周辺部にはせん断変形がほとんど生じな

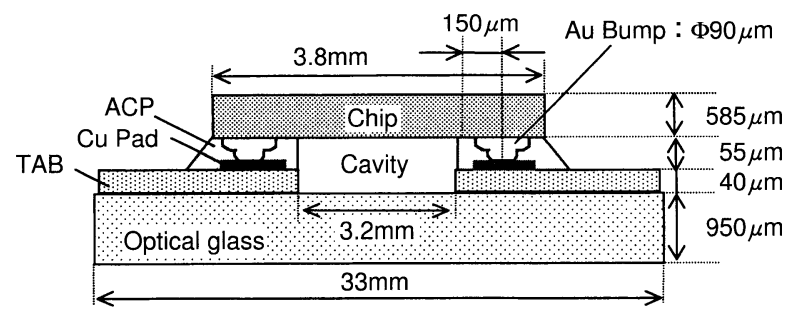

Fig.2 Cross section image of the TOG module

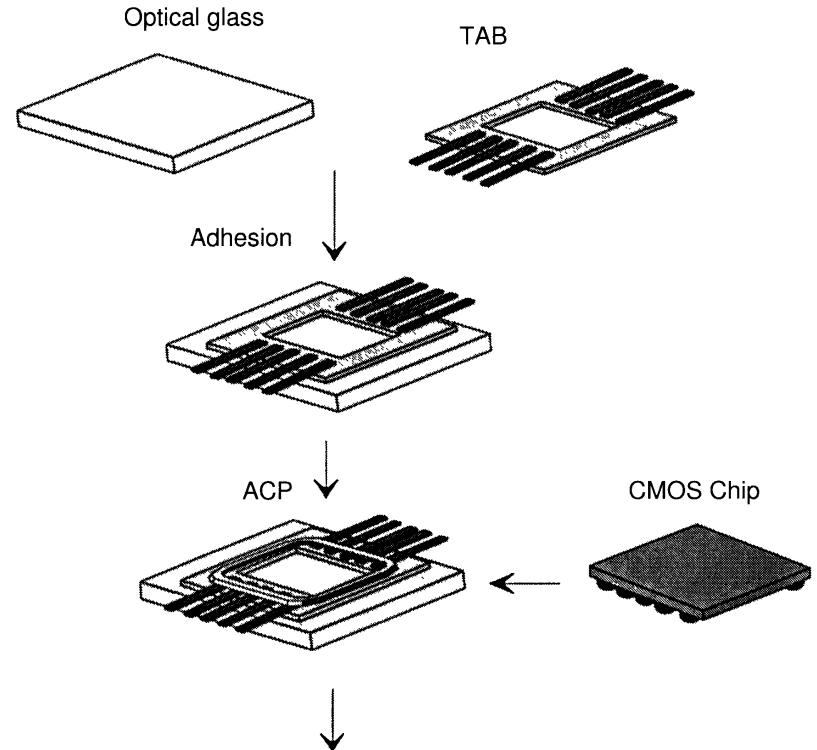

FC Bonding
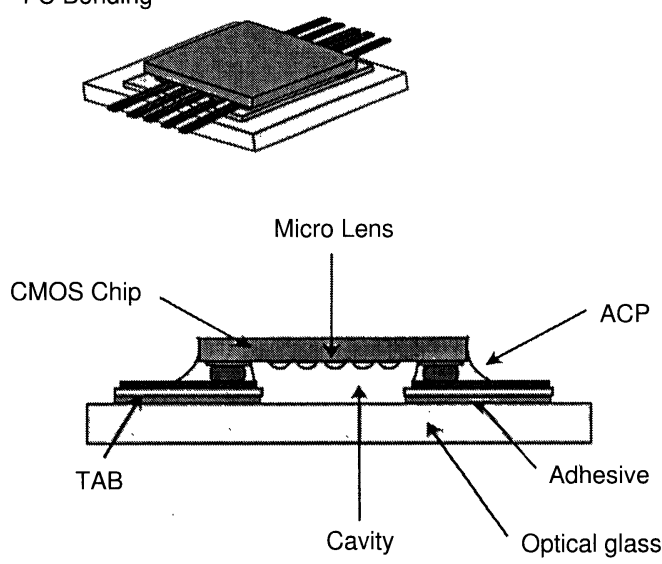

Fig.3 TOG module production process

いことが明らかになったため, バンプ周辺部の軸対称モデ ルにより応力解析を実施した。有限要素（FEM）モデル をFig. 4 に示す。バンプ中心部から樹脂端までの距離の最 小值 $150 \mu \mathrm{m}$ を対象領域半径とした。また，導電粒子が金バ ンプノパッド界面に存在しない場合を仮定してモデル化を 行った。

\section{3 材料特性評価}

解析に用いた弾性率，ポアソン比，線膨張率をTable 1 に示す。ただし，銅パッドおよび金バンプは塑性特性まで 考慮して解析を行った。硬化温度時の樹脂高温変形特性や 樹脂硬化収縮は最終的な金バンプノパッド界面圧縮荷重に 影響すると考えられる。以下に示す方法により特性を評価 した。今回評価した接続用樹脂はエポキシ樹脂に約 $\phi 5 \mu \mathrm{m}$ 


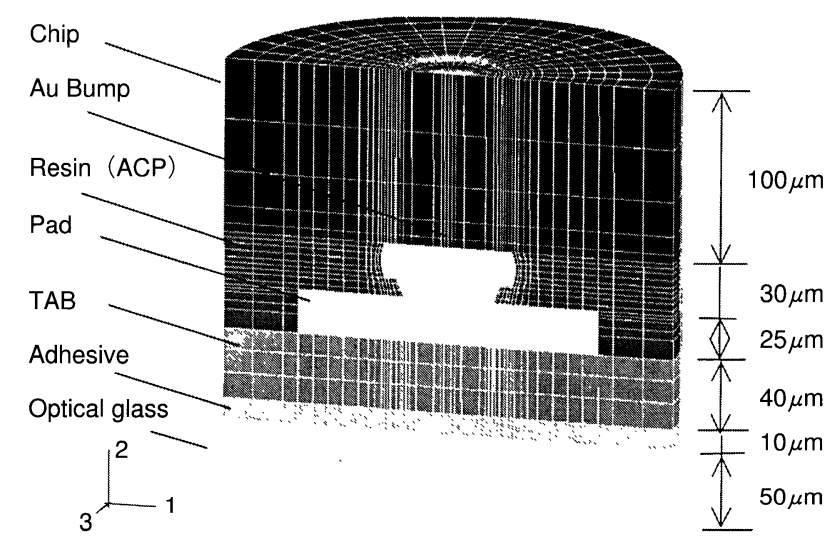

Fig.4 FEM model

Table 1. Material properties

\begin{tabular}{c|c|c|c}
\hline & $\begin{array}{c}\text { Young's } \\
\text { modulus }(\mathrm{GPa})\end{array}$ & $\begin{array}{c}\text { Poisson's } \\
\text { ratio }\end{array}$ & $\begin{array}{c}\text { Thermal expansion } \\
\text { coefficient }\left({ }^{\circ} \mathrm{C}\right)\end{array}$ \\
\hline $\begin{array}{c}\text { Resin }(\mathrm{ACP}) \\
\left(\mathrm{Tg}=115^{\circ} \mathrm{C}\right)\end{array}$ & $\begin{array}{c}2.0(\mathrm{RT}) \\
0.05\left(150^{\circ} \mathrm{C}\right)\end{array}$ & 0.3 & $\begin{array}{c}68 \times 10^{-6}(\mathrm{Tg} \text { 以下 }) \\
200 \times 10^{-6}(\mathrm{Tg} \text { 以上 })\end{array}$ \\
\hline Chip & 170 & 0.28 & $3.5 \times 10^{-6}$ \\
\hline $\mathrm{TAB}$ & 4 & 0.2 & $20 \times 10^{-6}$ \\
\hline $\mathrm{Au} \mathrm{Bump}$ & 88 & 0.34 & $20 \times 10^{-6}$ \\
\hline $\mathrm{Cu}$ Pad & 123 & 0.34 & $16.5 \times 10^{-6}$ \\
\hline Glass & 72 & 0.3 & $5.5 \times 10^{-6}$ \\
\hline
\end{tabular}

の導電粒子を分散させたもので，反応硬化剤をマイクロカ プセル化したことが特徴のACPである。

\section{3.1 高温変形特性の取得}

$10 \mathrm{~mm} \times 100 \mathrm{~mm}$ 厚さ $2 \mathrm{~mm}$ の樹脂試験片を作成し，長手 方向に引張り保持した後の応力変化を測定した。試験温度 は $150^{\circ} \mathrm{C}$ (樹脂硬化温度), 応力レベルは, 硬化時, 樹脂内 鉛直方向に発生する引張り応力を参考に設定した。結果， Fig. 5 に示すとおり，プロセス時間内（ 5 分以内）では応

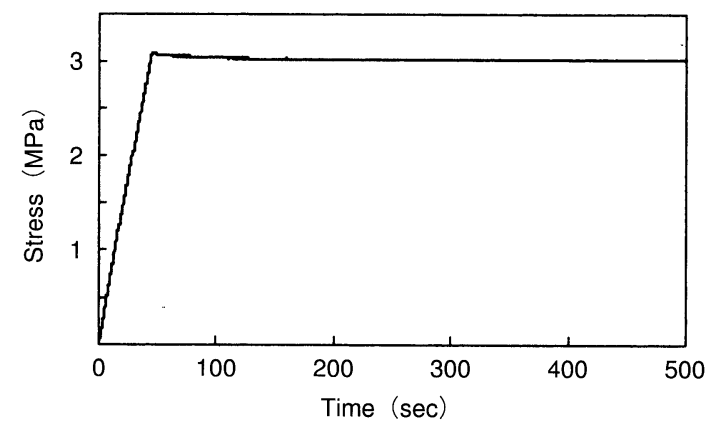

Fig.5 Variation of stress in resin

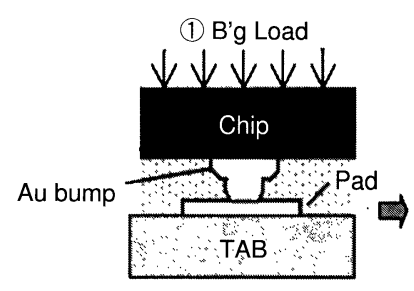

(2) Unload

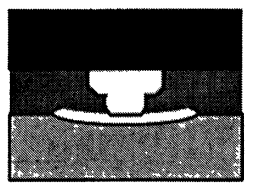

$\Rightarrow$

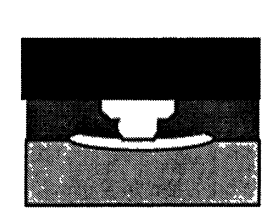

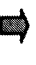

Bimetal specimen

Fig.6 Evaluation of resin shrinkage under resin curing

力の低下はわずかであり, 今回対象とした樹脂では $150^{\circ} \mathrm{C}$ で応力緩和は十分小さいと仮定した。

\subsection{2 硬化収縮特性評価}

$\mathrm{Si}$ 基板（100mm × 10mm，Si基板厚 $625 \mu \mathrm{m} ）$ 上に樹脂を $200 \mu \mathrm{m}$ 塗布後, $150^{\circ} \mathrm{C}$ まで昇温し硬化させ，硬化後室温ま で降温した（Fig. 6 参照）。樹脂硬化時（150 C）および降 温時の試験片反り量を測定した結果，硬化時には反りが生 じず，また室温時の反り量が $\mathrm{Si}$ と樹脂の線膨張率差による 反り量（計算值）とよい一致を示した。今回対象とした樹 脂では樹脂硬化収縮による反りはほとんど生じないことが 明らかになり，硬化収縮による金バンプ／パッド界面圧縮 荷重への影響は十分小さいと判断した。硬化収縮による反 りが生じない原因としては, 硬化収縮発生時の樹脂弾性率 が著しく小さいことが考えられる。また，樹脂によっては 硬化時に応力緩和する可能性も考えられる。

\subsection{3 膨潤特性}

吸湿前後の樹脂試験片 $(10 \mathrm{~mm} \times 100 \mathrm{~mm}$ 厚さ $2 \mathrm{~mm})$ 厚 さの変化を測定することにより膨潤率を算定した。今回対 象とした樹脂では, 吸湿条件が $60^{\circ} \mathrm{C} 90 \%$ の場合, 飽和膨 潤率（厚さ方向）は0.5\%であった。樹脂の種類によって は同条件で $2.0 \%$ 以上に達する場合もあり注意を要する。

\section{4 応カシミュレーションの流れ}

解析はFig. 7 に示すように，製造プロセスおよび樹脂の 膨潤を模擬した 4 ステップに分けて実施した。

(1) B'g荷重負荷（樹脂は未硬化のため，FEMモデルの 樹脂要素を削除して解析)。

(2) 樹脂の硬化後（FEMモデルの樹脂要素復活後）, B'g荷重除荷。

(3) 室温まで降温（ただし初期温度は $150^{\circ} \mathrm{C}$ )。

(4) 樹脂の体積膨張（樹脂膨潤を模擬）。

試作品において, バンプ接続部電気抵抗值のB'g荷重依 存性を実測した結果， $0.8 \mathrm{~N} / \mathrm{bump}$ 程度以上で良好な初期 接続を確保できることが明らかになった（Table 2 参照）。 また, B'g荷重が1.6N/bump以上では十分なチップーTAB 間ギャップが確保できず絶縁不良が発生する場合があっ
(3) Cooling down
(4) High temperature and humid test

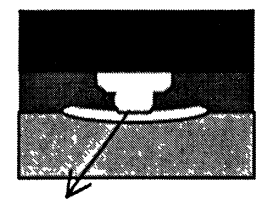

Load in Bump/Pad Interface

Fig.7 Flow of FEM analysis 
Table 2. Relationship between contact resistance and B'g load

\begin{tabular}{c|c}
\hline B'g load (N/bump) & $\begin{array}{c}\text { Condition of interconnection } \\
\text { (Contact resistance) }\end{array}$ \\
\hline Bellow 0.8 & High and Unstable \\
\hline $0.8 \sim 1.6$ & Low and Stable $(<10 \mathrm{~m} \Omega$ ) \\
\hline Above 1.6 & Unstable \\
\hline
\end{tabular}
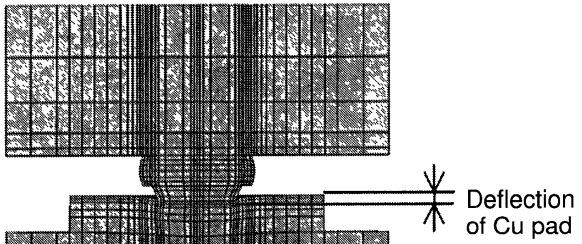

$1^{2}$ 3

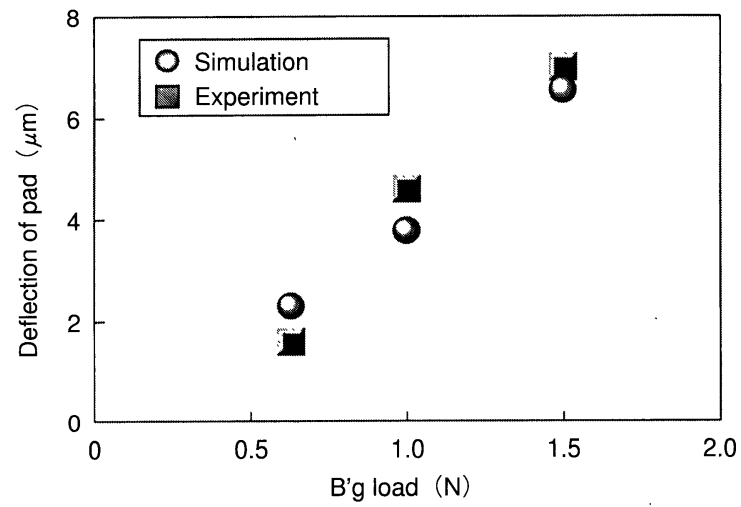

Fig.8 Comparison with simulation and experiment

た。接続マージンを考慮した適切值が存在すると考えられ る。よってここでは, $0.6,0.8,1.0,1.5 \mathrm{~N} /$ bumpの 4 ケー スについて解析を実施した。

まず，製造後のTOGモジュール断面写真から得られた 銅パッドたわみ量と解析結果を比較することにより，シミ ユレーション結果の検証を行った。Fig. 8 に比較結果を示 す。解析値と実測値でよい一致を示している。そこで，本 シミュレーションモデルによる接続マージンの定量化を試 みた。

プロセスの流れに沿って金バンプの鉛直方向圧縮荷重が 変化する様子を，1.0N/bumpの場合についてFig. 9 に示し ている。プロセスに沿って金バンプ／パッド界面圧縮荷重 が変化している様子がわかる。

今回対象とした圧着工法による接続では，金バンプと銅 パッド間には化学的な結合は生じておらず，金バンプ／パ ッド界面圧縮荷重により接続が保たれている。そこで金バ ンプノパッド界面の鉛直方向圧縮荷重により接続マージン を評価した。プロセスおよび樹脂膨潤をスルーした鉛直方 向圧縮荷重の変化図を1.0N/bumpの場合についてFig.10に 示す。

Fig.10では比較のため, Tg点以上で無応力の場合の結 果も併せて示している。B'g荷重負荷のプロセスやTg点以 上での樹脂高温変形特性の考慮により，プロセス終了後の

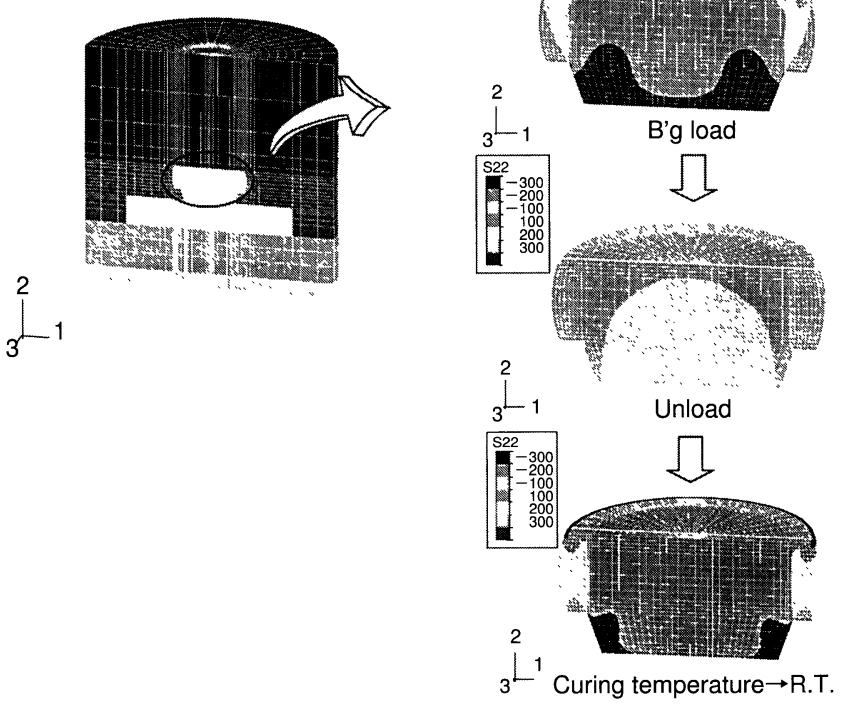

Fig.9 Variation of normal stress distribution in bump/pad interface

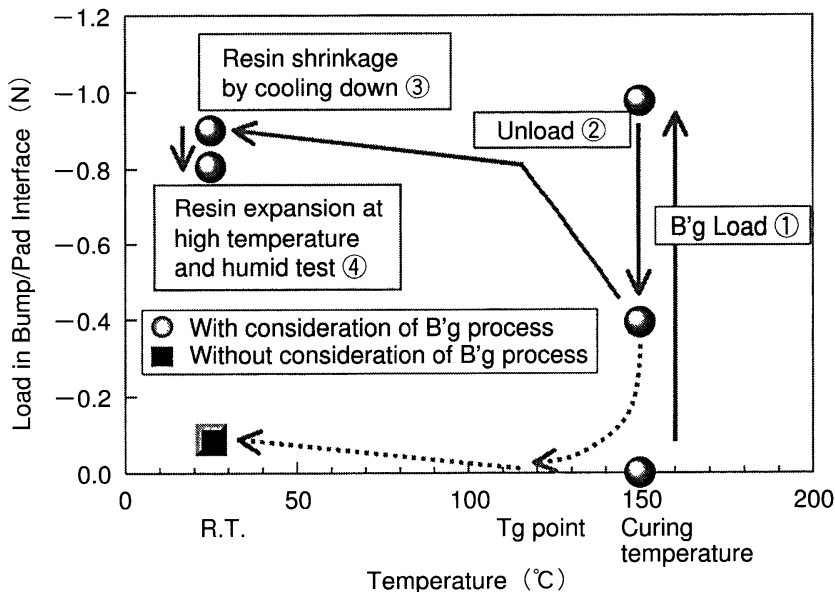

Fig.10 Variation of the load in bump/pad interface under flip-chip bonding sequence (In the case of B'g load 1.0N/bump)

鉛直方向圧縮荷重に大きな差がある。樹脂の高温変形特性 は，樹脂の種類や硬化温度に影響されると思われる。樹脂 の高温変形特性を考慮して樹脂および硬化温度を決定する ことが重要であると考えられる。製造プロセス後および樹 脂膨潤後（高温吸湿試験後）のバンプ下面鉛直方向荷重と B'g荷重の関係をFig.11に示している。0.8N/bump程度以 上で良好な初期接続を確保できることから $0.8 \mathrm{~N} / \mathrm{bump}$ の 場合の金バンプ／パッド界面圧縮荷重ー $0.7 \mathrm{~N}$ 基準と考え た。1.0N/bumpでは吸湿試験後，0.5\%の膨潤が生じた場 合においても $0.1 \mathrm{~N}$ 程度の接続マージンがあることがわか る。検討のため $2.0 \% の$ 膨潤率を仮定し解析を実施した結 果，Fig.11のム印に示すように，2.0\%では基準を下回って いる。金バンプ下面鉛直方向圧縮荷重により接続マージン を評価できると思われる。Fig.11では，B'g荷重とバン プ /パッド界面に生じる圧縮荷重はおおむね線形関係にあ るが，B'g荷重が1.6Nを超えたあたりから傾きが小さくな 


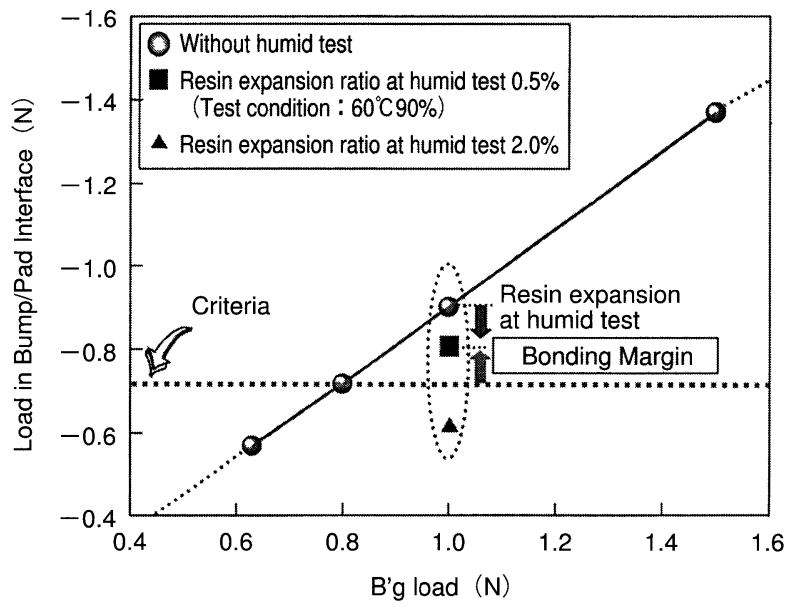

Fig.11 Relationship between B'g load and the load in bump/pad interface

る。これは, B'g荷重1.5N程度までは，金バンプが弾性変 形内であることを示している。パッド下の部材剛性， B'g 荷重，金バンプの降伏応力のバランスによっては，線形関 係を示すB'g荷重領域や傾きが異なると考えられる。

\section{3. 応答曲面法による公差解析 ${ }^{15)}$}

半導体パッケージの製造過程において，材料や製造プロ セスに，ばらつきが内在する。このため，個々の要素技術 の開発だけではなく, 多くのばらつき要因が応力や変形量 などの構造応答に及ほすす感度を統計的に把握した上で, 設 計を行う必要がある。本章では，設計に内在するばらつき 要因が，金バンプノパッド界面に生じる圧縮荷重や，チッ プ／TAB間のギャップへ及ぼす影響度を, 統計的手法を 用いることにより算定し，B'g荷重の設定や公差の設定を 支援することを試みた。

\section{1 応答曲面近似式の作成}

ばらつきの要因が，金バンプ／パッド界面に生じる圧縮 荷重やギャップといった構造応答に及ぼす影響度を効率良 く把握するために，応答曲面法 ${ }^{11)}$ 14) 用いる。設計に内在 するばらつき要因を変数とした近似式（応答曲面近似式） をそれぞれの構造応答について作成する。ここで, 応力解 析の数值実験点は直交表を用いた実験計画法により決定す る。Table 3 には，本対象において，顕著に内在すると考 えられるばらつき要因および仮想的に設定したばらつき範 囲 (公差) を示している。各要因の水準数は 3 水準，水準 間隔はばらつき範囲内で等間隔とし, L18の直交表に要因 の割付を行った。応答曲面近似式には, Chebyshevの直交 多項式 ${ }^{11)}$ を用いる。この近似式は, 各数值実験点（=直交 表の列）の解析結果を用いて作成する回帰式に相当するも のである。この直交多項式は, 低次項が優先され各次数項 が互いに独立であるという特徴をもっているため，任意の 次数で近似式を打ち切っても, 残った次数に扔いては最良 な回帰式を示している。構造応答を $\mathrm{y}$, 設計に内在するば らつき要因を $\mathrm{X}_{\mathrm{i}}$, 各ばらつき要因の平均值を $\mu_{\mathrm{i}}$ とするとき,
Table 3. Scatter variables and structural response

\begin{tabular}{c|c|c}
\hline & Scatter variables & Scatter range \\
\hline $\mathrm{X}_{1}$ & B'g load (N) & $1.2 \pm 50 \%$ \\
\hline $\mathrm{X}_{2}$ & Young's modulus of substrate (GPa) & $3.9 \pm 20 \%$ \\
\hline $\mathrm{X}_{3}$ & Young's modulus of underfill (GPa) & $2 \pm 20 \%$ \\
\hline $\mathrm{X}_{4}$ & C.T.E. of underfill (ppm $\left./{ }^{\circ} \mathrm{C}\right)$ & $68 \pm 20 \%$ (bellow $\mathrm{Tg})$ \\
& & $200 \pm 20 \%$ (above $\mathrm{Tg}$ ) \\
\hline
\end{tabular}

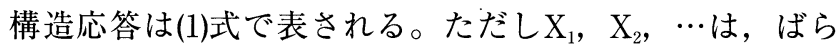
つき要因, $\mu_{1}, \mu_{2}, \cdots は$ 平均値, aは係数, $\mathrm{k}, \mathrm{h}$ は水準数, 水準間隔をそれぞれ示している。

構造応答 $y=a_{0}+a_{10}\left(X_{1}-\mu_{1}\right)+a_{20}\left[\left(X_{1}-\mu_{1}\right)^{2}\right.$

$$
\begin{aligned}
& \left.-\left(\mathrm{k}^{2}-1\right) \mathrm{h}^{2} / 12\right]+\mathrm{a}_{01}\left(\mathrm{X}_{2}-\mu_{2}\right)+\mathrm{a}_{02}\left[\left(\mathrm{X}_{2}-\mu_{2}\right)^{2}\right. \\
& \left.-\left(\mathrm{k}^{2}-1\right) \mathrm{h}^{2} / 12\right]+\mathrm{a}_{11}\left(\mathrm{X}_{1}-\mu_{1}\right)\left(\mathrm{X}_{2}-\mu_{2}\right) \\
& +\mathrm{a}_{21}\left[\left(\mathrm{X}_{1}-\mu_{1}\right)^{2}-\left(\mathrm{k}^{2}-1\right) \mathrm{h}^{2} / 12\right]\left(\mathrm{X}_{2}-\mu_{2}\right) \\
& \left.+\mathrm{a}_{12}\left(\mathrm{X}_{2}-\mu_{2}\right)^{2}-\left(\mathrm{k}^{2}-1\right) \mathrm{h}^{2} / 12\right]\left(\mathrm{X}_{1}-\mu_{1}\right)+\cdots(1)
\end{aligned}
$$

18ケースの応力シミュレーションを実施し，金バンプノパ ッド界面に生じる圧縮荷重，およびチップ／TAB間のギ ヤップ量を抽出し，それぞれについて，応答曲面近似式を 作成した。

高温吸湿後の金バンプ／パッド界面圧縮荷重（N)

$=0.964-0.679^{*} \mathrm{X}_{1}-0.000132^{*} \mathrm{X}_{1}{ }^{2}-0.0464^{*} \mathrm{X}_{2}+0.005 \mathrm{X}_{2}^{2}$

$$
-0.229^{*} \mathrm{X}_{3}+0.0389^{*} \mathrm{X}_{3}{ }^{2}-0.0116^{*} \mathrm{X}_{4}+0.0000593^{*} \mathrm{X}_{4}{ }^{2}
$$

チップ $/ \mathrm{TAB}$ 間のギャップ量 $(\mu \mathrm{m})$

$=44.4+0.00786 \mathrm{X}_{1}-0.000327 \mathrm{X}_{1}{ }^{2}+1.82 \mathrm{X}_{2}-0.150 \mathrm{X}_{2}^{2}$

$-7.48 \mathrm{X}_{3}+1.70 \mathrm{X}_{3}{ }^{2}-0.258 \mathrm{X}_{4}+0.00130 \mathrm{X}_{4}^{2}$

\section{2 分散分析}

各ばらつき要因の影響度を判断するために分散分析を行 う。分散分析には, 各要因が構造応答に与える影響度を多 項式の成分に直交分解して評価する方法を用いた。ここで, 影響度とは各要因の変動に伴う構造応答の変化の程度を表 している。この方法により影響度は応答曲面近似式を作成 する過程で 1 次， 2 次などのように分解された特性に対し て求めることができる。各構造応答について分散分析を行 った結果をTable $4 ， 5$ に示す。危険率の**，*はその 成分がおのおの $1 \% ， 5 \%$ 危険率で有意であることを示 す。今回仮想的に設定したばらつき範囲では, B'g荷重の ばらつきの寄与が大きいことが明らかになった。

\section{3 構造応答確率分布および不良発生確率の算出}

本来，ばらつき要因の確率分布は，十分な検査データか ら決定するべきであるが，ここでは仮想的に各要因のばら つきが独立に正規分布に従うと仮定し，Table 3 に示すば らつき範囲内に $99 \%$ の確率で存在すると設定した。ばらつ き要因の確率分布に従う乱数をそれぞれの要因について発 生させ, 応答曲面近似式より構造応答のばらつきを評価し た結果をFig.12に示す。不良発生基準值は, Table 2 に示 す実験結果から決定した。各構造応答について不良発生基 準值をTable 6 に示す。

構造応答のばらつき分布と, 不良発生基準值とを照らし 
Table 4. Analysis of variance for load between Au bump and $\mathrm{Cu}$ pad

\begin{tabular}{c|c|c|c|c|c}
\hline Factor & Dimension & $\begin{array}{c}\text { Degree of } \\
\text { freedom }\end{array}$ & Variance & F Ratio & $\begin{array}{c}\text { Contribution } \\
\text { Ratio }\end{array}$ \\
\hline B'g load & 1 & 1 & 34.5 & $1753.93 * *$ & $98.94 \%$ \\
& 2 & 1 & 0.100 & 5.30 & $0.24 \%$ \\
\hline $\begin{array}{c}\text { Young's modulus } \\
\text { of substrate }\end{array}$ & 1 & 1 & 0.0154 & 0.78 & $0.00 \%$ \\
\hline $\begin{array}{c}\text { Young's modulus } \\
\text { of underfill }\end{array}$ & 1 & 1 & 0.00904 & 0.46 & $0.00 \%$ \\
\hline C.T.E. of underfill & 1 & 1 & 0.0652 & 3.32 & $0.13 \%$ \\
& 2 & 1 & 0.000969 & 0.05 & $0.00 \%$ \\
\hline Error & & 9 & 0.00170 & 0.09 & $0.00 \%$ \\
\hline Total & & 1 & 0.0140 & 0.72 & $0.00 \%$ \\
\hline & & $*: \mathrm{F}(0.05)=5.591447$ & $* *: \mathrm{F}(0.01)=12.24638$ & $0.68 \%$ \\
\hline
\end{tabular}

Table 5. Analysis of variance for gap between chip and TAB

\begin{tabular}{|c|c|c|c|c|c|c|}
\hline Factor & Dimension & $\begin{array}{l}\text { Degree of } \\
\text { freedom }\end{array}$ & Variance & F Ratio & & $\begin{array}{c}\text { Contribution } \\
\text { Ratio }\end{array}$ \\
\hline B'g load & $\begin{array}{l}1 \\
2\end{array}$ & $\begin{array}{l}1 \\
1\end{array}$ & $\begin{array}{r}241.76 \\
10.28\end{array}$ & $\begin{array}{r}247.65 \\
10.53\end{array}$ & ** & $\begin{array}{r}85.58 \% \\
3.31 \%\end{array}$ \\
\hline $\begin{array}{l}\text { Young's modulus } \\
\text { of substrate }\end{array}$ & $\begin{array}{l}1 \\
2\end{array}$ & $\begin{array}{l}1 \\
1\end{array}$ & $\begin{array}{r}18.84 \\
1.31\end{array}$ & $\begin{array}{r}19.30 \\
1.34\end{array}$ & $* *$ & $\begin{array}{l}6.35 \% \\
0.12 \%\end{array}$ \\
\hline $\begin{array}{l}\text { Young's modulus } \\
\text { of underfill }\end{array}$ & $\begin{array}{l}1 \\
2\end{array}$ & $\begin{array}{l}1 \\
1\end{array}$ & $\begin{array}{l}0.92 \\
0.29\end{array}$ & $\begin{array}{l}0.94 \\
0.30\end{array}$ & & $\begin{array}{l}0.00 \% \\
0.00 \%\end{array}$ \\
\hline C.T.E. of underfill & $\begin{array}{l}1 \\
2\end{array}$ & $\begin{array}{l}1 \\
1\end{array}$ & $\begin{array}{l}0.02 \\
1.08\end{array}$ & $\begin{array}{l}0.02 \\
1.11\end{array}$ & & $\begin{array}{l}0.00 \% \\
0.04 \%\end{array}$ \\
\hline Error & & 9 & 0.76 & & & $4.61 \%$ \\
\hline Total & & 17 & & & & $100.00 \%$ \\
\hline & & \multicolumn{4}{|c|}{$*: \mathrm{F}(0.05)=5.591447 \quad * *: \mathrm{F}(0.01)=12.24638$} & \\
\hline
\end{tabular}
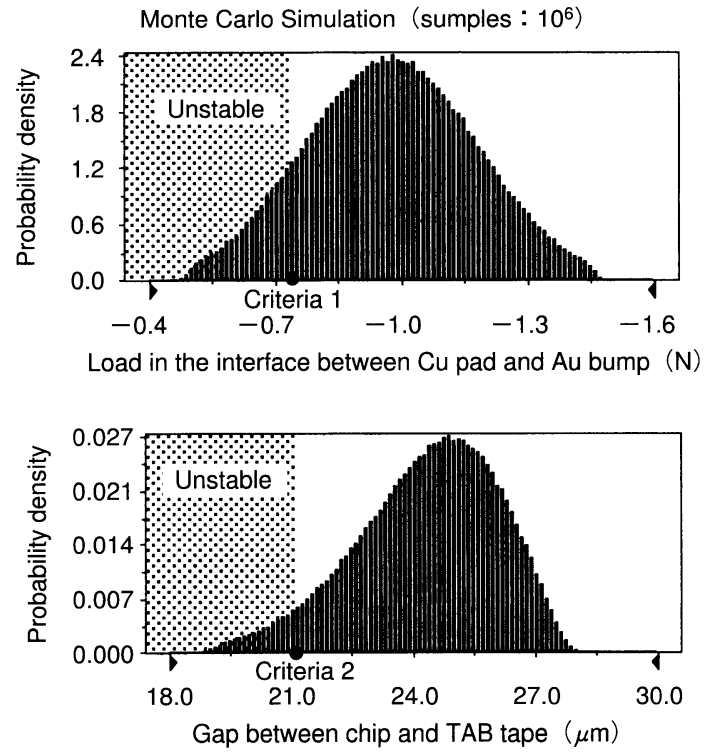

Fig.12 Probability distributions for structural response values

合わせ，モンテカルロ法（試行回数 $10^{6} ，$ ばらつき要因の 範囲外はカット）により不良発生確率 $P_{\mathrm{f}}$ 算出した結果を Table 7 に示す。複数の構造応答が存在する場合でも，同 時確率を求めることができ，不良発生確率 $\mathrm{P}_{\mathrm{f}}$ を指標に, B'g荷重の設定やばらつき要因公差の設定を行うことが可 能である。今回仮想的に想定したばらつき要因分布では,
Table 6. Criteria for fracture

\begin{tabular}{c|c}
\hline Criteria 1 & Criteria 2 \\
\hline $\begin{array}{c}\text { Load in the interface between } \\
\mathrm{Cu} \text { pad and Au bump }(\mathrm{N})\end{array}$ & $\begin{array}{c}\text { Gap between chip and TAB tape } \\
(\mu \mathrm{m})\end{array}$ \\
\hline-0.702 & 21.2 \\
\hline
\end{tabular}

Table 7. Probability of failure $\mathrm{P}_{\mathrm{f}}$

\begin{tabular}{c|c|c}
\hline $\mathrm{P}_{\mathrm{f}}$ for criteria 1 & $\mathrm{P}_{\mathrm{f}}$ for criteria 2 & $\mathrm{P}_{\mathrm{f}}$ for criteria land criteria 2 \\
\hline 0.0967 & 0.0501 & 0.147 \\
\hline
\end{tabular}

B'g荷重に注目した場合，目標値を1.25N，ばらつき範囲を 目標值 $\pm 20 \%$ に設定する必要があることが，モンテカルロ シミュレーションを繰り返し実行することにより明らかに なった。不良発生確率 $\mathrm{P}_{\mathrm{f}}$ の算出には，応答曲面近似誤差や 考虑外のばらつき要因などの不確かさが存在する。しかし ながら，実用上，設計案の相対比較には，同程度に不確か さが内在するため有効であると考えられる。

\section{4. まとめ}

圧着工法によるフリップチップでは，多くの場合，接続 用樹脂を介してチップのスタッドバンプと基板電極を熱圧 着し接続を行う。樹脂選定やボンディング荷重（B'g荷重） の設定によっては，高温・吸湿試験において樹脂の膨潤に 
より接続オープンや電気抵抗の上昇が発生する場合があ り，長期信頼性を確保するには，樹脂特性やB'g荷重の影 響度の明確化が重要課題になる。本報告では, 応力シミュ レーションを実施し, 試作品初期接続抵抗值のB'g荷重依 存性結果と照らし合わせ，バンプ接合部の接続マージンを 定量化した。

その結果は以下のようにまとめられる。

(1) 小型画像センサモジュールをモチーフに, 接続用 樹脂特性評価および応力シミュレーションを実施し， 金バンプ／パッド界面の鉛直方向圧縮荷重により接続 マージン評価を行った。試作品の初期接続抵抗值 （B'g荷重依存性）結果より明らかになった基準值と照 らし合わすことにより，接合部の接続マージンを定量 化できることを示した。

(2) 金バンプ／パッド界面に生じる圧縮荷重，および チップ /TAB間のギャップ量といった構造応答を, ばらつき要因を変数とする関数として，近似的に表現 する応答曲面近似式により，ばらつき要因が構造応答 に及ぼす影響度を効率的に把握することが可能にな る。複数の構造応答の評価が必要な場合でも，同時確 率を指標に, B'g荷重の設定やばらつき要因公差の設 定を行うことが可能である。

\section{謝 辞}

本研究を実施するにあたり有益なご助言をいただいた東 芝研究開発センター・菊入信孝氏, 大嶺俊光氏, 試験実施 にご協力いただいた東芝生産技術センター・唐沢 純氏, 小野美智子氏, 東芝デジタルメディアネットワーク社・青 木 慎氏, 東芝ケミカル・岸本泰一氏に感謝致します。

(2001.5.15-受理２001.8.20-再受理)

\section{文献}

1) M.Segawa, M.Kimura, K.Ooi, S.Sugi : "A Micro Miniaturized CCD Color Camera Utilizing a Newly Developed CCD Packaging Technique”, IEEE Trans.on Consumer Electronics, Vol.41, No.3, August, pp.946-953, 1995

2) 小野美智子, 瀬川雅雄, 杉 修一, 木村正信, 大井一成, 岸本泰一：“ $\Phi 4 \mathrm{~mm}$ マイクロカメラ用小型画像センサーモ ジュール”, 第 7 回マイクロエレクトロニクスシンポジウム, MES’97, pp.29-32, 1997
3) M.Segawa, M.Ono, S.Musha, Y.Kishimoto, A.Ohashi : “A CMOS Image Sensor Module Applied for a Digital Still Camera Utilizing the TOG Bonding Method", ECTC Proc., pp.1109-1114, 1998

4) 瀬川雅雄, 小野美智子, 青木 慎: “異方性導電接続法を用 いたデジタルカメラ用画像センサーモジュール”, $5^{\text {th }}$ Symposium on Microjoining and Assembly Technology in Electronics, pp.183-188, Feb.1999

5) 加藤俊夫 : “フリップチップ実装技術の現状と今後の課題”, エレクトロニクス実装学会誌, Vol.2, No.5, pp.404-409, Sep. 1999

6) 佐藤武彦：“導電性接着剂接続技術”，エレクトロニクス実 装学会誌, Vol.10, No.6, pp.373-376, Sep. 1995

7) 武市元秀：“ベアチップ実装用ACF”，エレクトロニクス実 装学会誌, Vol.2, No.2, pp.95-98, Mar.1999

8）竹村賢三，長井 朗，渡辺伊津夫：“フリップチップ接続用 異方導電材料”, 回路実装学会誌, Vol.2, No.2, pp.99-103, Mar. 1999

9) 土谷雅弘：“導電微粒子の電気的特性評価”, マイクロ接合 研究委員会資料（MJ-301-97），pp.35-45，Dec. 1997

10) 廣畑賢治, 川村法靖, 向井 稔, 川上 崇, 瀬川雅雄, 小 野美智子：“圧着工法によるフリップチップの接続マージン 評価”，第14回エレクトロニクス実装学術講演大会, pp.101102,2000

11) 柏村孝義, 白鳥正樹, 于 強: “統計的最適化手法における ばらつきと構造信頼性の評価”, 機論, 63-610, A, pp.222227, 1997

12) 柏村孝義, 白鳥正樹, 于 強：“実験計画法による非線形問 題の最適化”, 朝倉書店, 1998

13) R.H.Myers, D.C.Montgomery : "Response Surface Methodology : Process and Product Optimization Using Designed Experiments", John Wiley \& sons, 1995

14) 廣畑賢治, 向井 稔, 川村法靖, 川上 崇, 于 強, 白鳥 正樹：“統計的手法を用いた電子機器はんだ接合部の構造信 頼性設計”, 機構論, No.00-19, pp.511-512, 2000

15) 廣畑賢治, 川村法靖, 向井 稔, 川上 崇, 瀬川雅雄, 于 強, 白鳥正樹：“統計的手法を用いたフリップチップパッケ ージの構造信頼性設計”, 計算工学講演会論文集, Vol.6, pp.673-676, 2001 